\title{
Effects of the European Union Agricultural and Environmental Policies in the Sustainability of Most Common Mediterranean Soils
}

\author{
José Manuel Rato Nunes 1,2,* (D) António Bonito ${ }^{2}$, Luis Loures ${ }^{2,3}$ (i) , José Gama ${ }^{2,4}$, \\ Antonio López-Piñeiro ${ }^{4}$, David Peña ${ }^{4}$ and Ángel Albarrán ${ }^{5}$ \\ 1 Instituto Superior de Agronomia, University of Lisbon, LEAF, Linking Landscape, Environment, \\ Agriculture and Food, Tapada da Ajuda, 1349-017 Lisboa, Portugal \\ 2 Instituto Politécnico de Portalegre, Escola Superior Agrária de Elvas, Av. 14 de janeiro 21, \\ 7350 Elvas, Portugal; antonio.bonito@gmail.com (A.B.); lcloures@esaelvas.pt (L.L.); \\ zeigama@gmail.com (J.G.) \\ 3 CIEO-Centre for Spatial and Organizational Dynamics, Universidade do Algarve, Campus de Gambelas, \\ 8005-139 Faro, Portugal \\ 4 Área de Edafología y Química Agrícola (Facultad de Ciencias) and IACYS, Universidad de Extremadura, \\ Avda de Elvas s/n, 06071 Badajoz, Spain; pineiro@unex.es (A.L.-P.); davidpa@unex.es (D.P.) \\ 5 Área de Producción Vegetal (Escuela de Ingenierías Agrarias) and IACYS, Universidad de Extremadura, \\ Ctra. de Cáceres, 06071 Badajoz, Spain; angliso@unex.es \\ * Correspondence: ratonunes@esaelvas.pt; Tel.: +351-268-628-528
}

Received: 8 June 2017; Accepted: 7 August 2017; Published: 9 August 2017

\begin{abstract}
Agro-environmental measures promoted by the European Union focus mainly on environmental protection by maintaining sustainable levels of productivity that are adequate to the agro-ecological conditions of each region on different Member States. Among these European Union promoted measures the one known as "Extensive Forage Systems" is particularly relevant for the Mediterranean Region. In order to analyze the impact of this measure and to verify if the high expenditure of communitarian funds, with its implementation in Mediterranean soils, is aligned with the predicted benefits, a seven-year study in a southern Portugal region was conducted. In this regard, several soil chemical parameters such as organic matter, $\mathrm{pH}$, electrical conductivity, "available" phosphorus, "available" potassium and heavy metal levels $(\mathrm{Cd}, \mathrm{Cr}, \mathrm{Cu}, \mathrm{Zn}, \mathrm{Mn}, \mathrm{Pb}$ and $\mathrm{Ni}$ ), were assessed, in 1329 different plots in order to represent some of the existing diversity of the Mediterranean environment, identified by the Portuguese Parcel Identification System, and considering the possibility to evaluate the evolution of these parameters on the main soil types of the region. The obtained results enabled us to verify that the application of the agro-environmental measure "Extensive Forage Systems" did not lead, during the 7 years of the study, to any significant change in terms of organic matter, soil pH and/or heavy metals content. Still it contributed for a small growth on "available" phosphorus and potassium levels and to a significant increase on Soil electrical conductivity (EC). As a final conclusion we can refer that the application of the agro-environmental measure "Extensive Forage Systems", in soil, clime and cultural conditions prevailing in this study (Typical Mediterranean conditions from the South of Europe), did not reach its main objective, which was to increase the organic matter content in soils.
\end{abstract}

Keywords: community subsidies; agro-environmental measures; Extensive Forage Systems; Mediterranean environment; soil chemical parameters 


\section{Introduction}

Agricultural and Forestry landscapes occupy a large area of the European territory [1,2]. Approximately one-half of the European Union's (EU) agricultural area is occupied by land for cultivation, whether for annual crops or pasture for animal feed, which reflects both the impact and importance of agriculture and livestock sectors, not only in the vitality of rural economies [3] but also, in maintaining rural environments [4,5]. Agriculture is much more than crop and animal production aiming to produce goods to feed an increasing population [1,6]. In fact, even if farmers' activity consists in the production of foodstuffs, in this activity they jointly apply ancestral techniques with the support and use of available scientific and technological measures with the aim to provide quality food products at the lowest possible price [5,7]. For this reason, the level of technical and professional demand, for the agricultural producers is currently very high and complex [8]. Additionally, EU agricultural policies are increasingly oriented towards combating and reducing the risks that agriculture may have in the environment [9], encouraging farmers to environmental conservation and ecological practices through specific rural development measures while, at the same time, assuring the profitability of agriculture $[5,10]$. These agro-environment measures (i.e., support for organic farming, agricultural conservation practices, protection and maintenance of terraces, safer use of pesticides, integrated crop management, management of less intensive grazing systems, reduction of animal stocking and the utilization of certified compost [11,12]) offer the opportunity to increase soil's organic matter content and its biodiversity, while helping to reduce its erosion, contamination and compaction.

The Common Agricultural Policy (CAP), in its global agro-environmental strategy, is geared towards enhancing the sustainability of agricultural ecosystems [13-15], particularly from a water and soil perspective [16]. Measures established to integrate environmental aspects into the CAP [17] include environmental requirements and incentives such as the removal of set-aside or the specific environmental measures integrated in the rural development programs as the Agro-Environmental Measures (AEM) $[8,18,19]$. In the Mediterranean region, the AEM are composed by horizontal measures relevant to the entire territory or solely for specific regions, addressing specific agricultural problems and giving support to extensive traditional systems [20].

In order to apply to the "Extensive Forage Systems" measure, which is the farmers most adopted measure in South European Counties [21] and whose efficiency will be tested in this study, the applicant must comply to the following aspects [20]: (i) the beneficiaries need to present a pasture management plan approved by the respective Regional Agriculture Department (RAD) and whose production units meet specific pre-established conditions; (ii) natural pastures should be located in areas that have not been subject to sowing and soil mobilization in the last two years; (iii) in the case of grassland in a natural meadow systems, known as montado, with the maximum density of 40 trees per hectare shall be taken into account, except, in the case of Quercus rotundifolia, Quercus nigra or Quercus suber where there is no maximum density and in the case of olive groves where the density of 60 Olea europea trees per hectare is to be considered. If the farmers meet the above requirements and apply for financial support under this measure, they assume to comply with the pasture management plan; to maintain $90 \%$ of the soil covered with grass in the period from November to March; not to make cuts for hay, except if it is a cultural maintenance technique, outside the nesting season; not to plow, except in the case of re-sowing permanent meadows and for good agricultural technique reasons, always after technical opinion of the RAD; to provide compatible management with the level of forage production and the support capacity of the natural environment; to Keep the pasture area free of shrubs and semi-shrub weeds by cleaning it without soil mobilization, unless authorized by the RAD, with the minimal and always localized use of light machinery prioritizing hand cleaning whenever possible or using contact herbicides applied with the appropriate equipment; to maintain the tree layer if present; to Maintain the arboreal and shrub vegetation along riparian zones; to maintain the water points belonging to the production unit with accessible water to wildlife during the period from May to November inclusively [20].

Besides these generic guidelines, which establish several legal requirements farmers need to follow in order to be able to benefit from these measures [20], there is still a requirement for soil 
chemical analyzes, at least every 2 years, considering specific parameters. The chemical analyzes recommended for the adoption of this agro-environmental measure are the ones presented in this work, namely soil organic matter, $\mathrm{pH}$, electrical conductivity, assimilable phosphorus and potassium, and some heavy metals and metalloids [20]. For the region under study, some of these parameters will be more important than others in order to increase the sustainability of these agro-systems, due to the adoption of these agro-environmental measures. However, this is a measure of great transversality in the Mediterranean basin, covering therefore very diverse regions, hence a set of parameters potentially relevant to all possible situations have been chosen. In fact, if in a predominantly rural area of low population density and low industrialization, as is the case of the region under analysis, the parameters related to heavy metals and metalloids will not be of great importance, since contaminations with these elements are not predictable, in an area closer to a large city or an industrial center, this parameter and its evolution, may represent an important source of information, regarding the implementation of this environmental measure [22,23].

However, even if all the measures are adequately defined, there is still a lack of understanding as to whether these EU policies, aimed to promote the sustainability of agro-systems and in particular of the soil [24], do in fact have some effectiveness, or if, on the contrary, they correspond to a waste of Community funds without any repercussions on environmental preservation. Since the Mediterranean soils are particularly vulnerable [21] with physic-chemical and biological characteristics that lead to their dilapidation it is important to analyze how some of the chemical parameters of the soils subject to EU-funded conservation practices evolve, over a relatively long period of time, so that we can verify and discern the effectiveness of these community policies. Among the most important parameters for analyzing the effectiveness of EU environmental policies regarding soil conservation is organic matter content [25]. As a matter of fact, the Mediterranean climate, due to its peculiarities, such as the concentrated rainfall coinciding with winter months with low temperatures and low luminosity, leads to low yields [1] which, combined with its characteristics suitable for soil biological activity, lead to typically low organic matter [26-28] in the soils of this region [22], which according to several authors, [22,29] are generally below $1.5 \%$. This aspect is particularly important since organic matter plays a fundamental role on the chemical, physical and biological fertility of the soil [29]. Among the attributes endorsed to the soil organic matter is the ability to retain water and cation nutrients and the ability to promote the aggregation of soil constituents [26] or the promotion of biological activity [30,31]. Among these functions, we emphasize as particularly important in the Mediterranean conditions the agglutinating effect of soil particles [32] given that a soil with a strong and adequate structure is certainly a soil that is more resistant to erosive phenomena [31] which represents one of the main threats to the sustainability of Mediterranean ecosystems [22]. Moreover, EU policies aiming to increase the sustainability of existing Eco-Agro-Systems promote also the analysis of several other soil parameters [20] considered of great important to guarantee the continuity of these fragile agricultural systems [33], as is the case of $\mathrm{pH}$ and the concentration of heavy metals [23,29].

Regarding soil $\mathrm{pH}$, it is of great importance considering the trend to acidity of some Mediterranean soils, particularly in the study region $[29,33]$ (constraining the production in these latitudes $[29,30,33]$ ). In this parameter, although a great evolution is not to be expected, we may have some interesting effects to analyze. Thus, if on the one hand the increase in the organic matter content will inevitably lead to a higher soil buffering power [34], on the other hand the biological oxidation process of the organic matter is essentially an acidifying process [29], which could lead to a decrease in soil pH. If we add to this a smaller use of synthetic fertilizers, then we will have a set of processes of antagonistic influence on the $\mathrm{pH}$ of the soil, whose final consequence will depend on the specific weight that each of these processes represent. With regard to the EC, extensive forage systems using a smaller quantity of synthetic fertilizers, a gradual decrease of EC from the soil is obviously expected. However, this effect may be contrary to what is expected in the most superficial layer of the soil, since the lack of mobilization inherent to this agro-environment measure may, in a first phase, lead to significant increases in soil EC [35]. On the other hand, drainage improvement expected in a soil with better 
structure, obtained by a predictable increase of the organic matter content of the soil, will lead to a more efficient washing of the salts with the corresponding decrease of the EC of the soil [36].

In relation to potassium and phosphorus soil content, the analysis of the evolution of these parameters as a consequence of the adoption of this agro-environmental measure are very relevant, given that in most of these agro-systems they present a decreasing tendency [36], being necessary to add it to the soil in an artificial way. In the case of phosphorus, its soil content is even more relevant, as it is directly related to the ease of rooting of meadow species $[37,38]$ playing a fundamental role in the successful implementation of extensive forage systems [30]. In fact, phosphorus is, in most cases, the only nutrient added artificially to the soil in these agro-systems [29].

On the other hand, it is commonly accepted that different soil types behave in diverse ways regarding the evolution of their chemical parameters [39,40]. While there are soils with greater power to oppose changes in their chemical composition, there are others very sensitive to these changes [29,30]. This fact has been clearly demonstrated, for example, in the work carried out on the same region where it has been possible to verify that Vertisols have an ability to mitigate the changes imposed by irrigation practices, which are significantly higher in other soil groups, as is the case of the Luvisols or even the Cambisols [41,42]. Recent researches on different areas, have also demonstrated similar findings regarding other parameters, as is the case of the evolution of organic carbon content in the soil [37], and phosphorus concentration in different types of soil subject to similar agricultural practices [38].

Considering all the aforementioned aspects, we outlined and conducted this study with the objective of analyzing the influence and effectiveness of specific EU policies-aimed at the environmental preservation-considering essentially the measure "Extensive Forage Systems", and its impact on increasing the sustainability of the rain-fed agricultural ecosystems in the Mediterranean environment.

\section{Material and Methods}

\subsection{Study Area and Experimental Design}

This study was developed in Center-East Portugal in a region alongside the Spanish border. The experimental zone was located in the Portuguese region of Alto Alentejo, District of Portalegre. This district extends over an area of $6086 \mathrm{~km}^{2}$ (Figure 1).

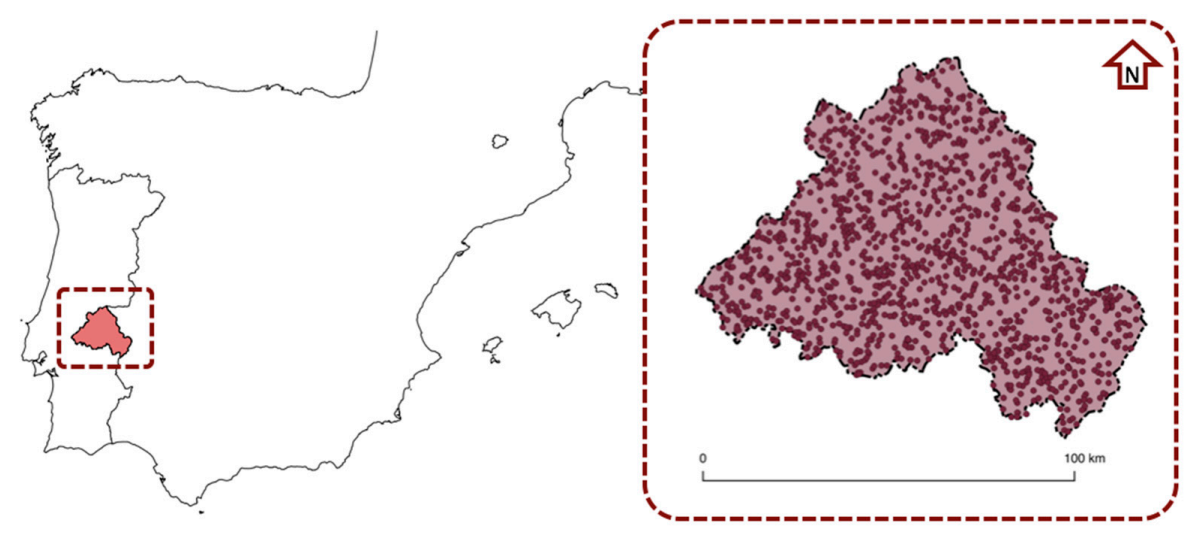

Figure 1. Sampling point distribution over the Map of the Portalegre District.

\subsection{Edaphic Characterization}

In the study area (Portalegre district) the most frequent types of soils are the Luvisols $\left(2337 \mathrm{~km}^{2}\right.$ and 527 sampling points-38.3\%) Cambisols (1993 $\mathrm{km}^{2}$ and 386 sampling points-32.7\%) and Podzols (1204 km $\mathrm{km}^{2}$ and 290 sampling points-19.7\%) and also, with less representability, Leptosols (513 $\mathrm{km}^{2}$ and 114 sampling points- $8.4 \%$ ), in the Northeast part of the district and, in a very small part, Vertisols (40 
$\mathrm{km}^{2}$ and 9 sampling points- $0.7 \%$ ), in the center of the district [43] (Figure 2). The soils are generally acidic with the exception of those developed on lands with a carbonate component or predominantly basic granitic rocks [44].

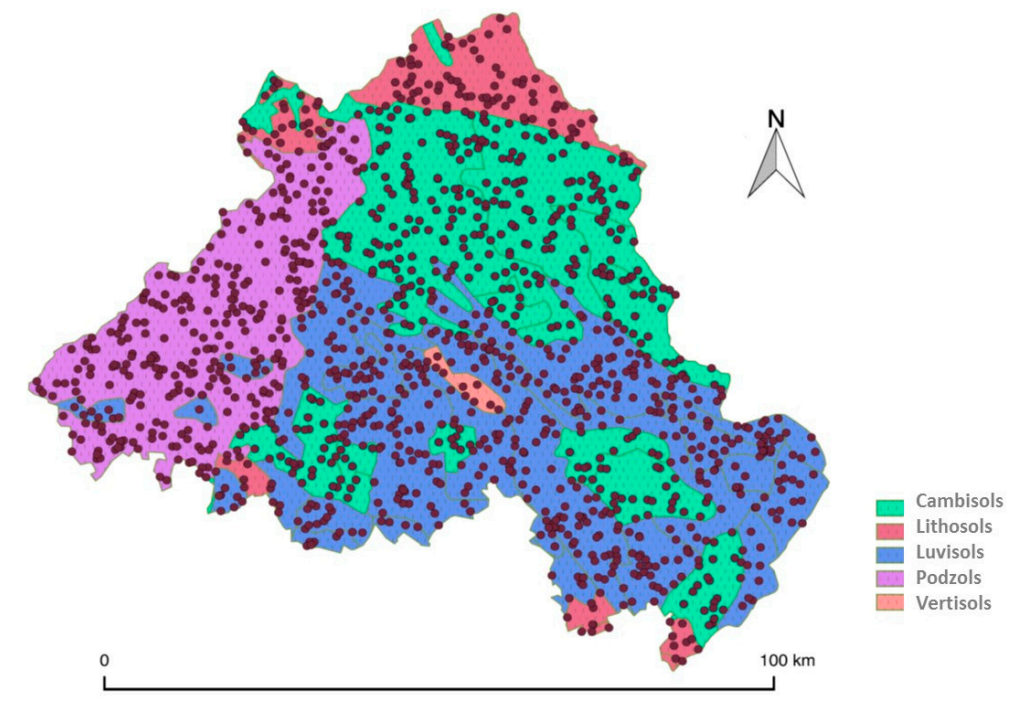

Figure 2. Food and Agriculture Organization (FAO) Soil classification map-overlapped to the study area [36].

\subsection{Climatic Characterization}

According to the Koppen classification the climate of the study area is classified as Type C, with incidence in the subtype Cs-seasoned climate with dry summer-and variant Csa-temperate climate with hot and dry summer $[45,46]$. The average air temperature in the region under study is above $15^{\circ} \mathrm{C}$ and only in a small Northeast area are the average temperatures between 10 and $15^{\circ} \mathrm{C}$ (Figure 3).

In general, low rainfall is observed in the region under study being always below the $1000 \mathrm{~mm}$ (Figure 3). The average annual rainfall is approximately $483 \mathrm{~mm}$ coinciding mostly with the coolest temperatures (October to March).
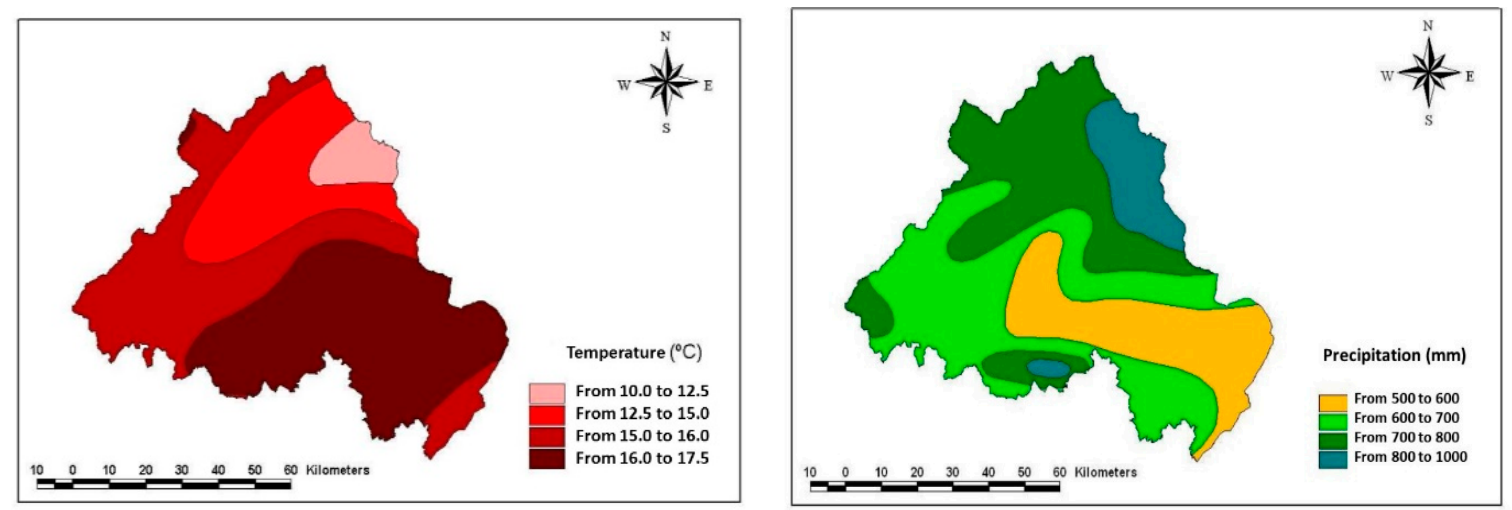

Figure 3. (Left) Distribution of annual mean air temperature values in the Portalegre District; (Right) Distribution of mean annual rainfall values in the Portalegre District.

\subsection{Soil Sampling}

For the purpose of this study the identification of the exact location of each of the agricultural parcels, where the soil samples were collected, was accomplished through the use of the Portuguese 
Agricultural Parcel Database, also designated as Parcel Identification System (PIS), which is a key component in the management of subsidies not covered by the CAP. PIS purpose is to allocate a single number to each element of the farm (parcel, building and/or plot group) in order to allow the geographical reference of agricultural properties in an unified and coherent way and to identify the graphical elements necessary both for the calculation of Community Subsidy and for control actions. The used methodology was to randomly collect, along the identified PIS plots, at least 10 subsamples, collected at a depth of 0 to $20 \mathrm{~cm}$, using a stainless-steel sampling probe, that would be carefully mixed in order to become a single sample. The selected depth was based on the regular depth used by farmers for their regular analysis, following the recommendations' from national soil chemistry analysis laboratories. Each sample would then be duly packed in sterile plastic bags and labeled with the PIS reference and the date of collection. Then the samples were sent to the Laboratory where it would be air dried and then sieved by a $2 \mathrm{~mm}$ rectangular mesh stainless steel screen. After this phase the sample follows to the analysis process itself.

In this study 1329 plots of land, randomly distributed over the 15 municipalities of Northeast Alentejo (Portugal), were monitored over a 7-year span-between 2003 and 2009. Each parcel corresponded to a single PIS so it was possible to guarantee that the parcel was always the same. The previous agricultural use of these parcels was very diversified. Although we do not have concrete data, our knowledge of the region leads us to report that most of the area would already be under extensive grazing, another part would be exploited in the production of rainfed autumn/winter crops, mainly wheat and oats, and a third part would be fallow without any agricultural use.

\subsection{Analysis}

In the laboratory, the chemical analysis of the soil was carried out determining the following parameters: organic carbon, $\mathrm{pH}$, electrical conductivity, "available" phosphorus and potassium, aluminum, cadmium, chromium, copper, iron, manganese, nickel, lead and zinc. These were the analysis carried out since they are the ones required by the national control bodies for the payment of Community subsidies.

\subsection{Organic Carbon}

Organic Carbon was determined by the wet oxidation method, commonly referred to as the Walkley-Black method, [47,48].

\section{7. $p H$}

$\mathrm{pH}$ was determined by potentiometer in a mixture of soil and water-1:5 $(v / v)$. The potentiometer used was a METROHM $692 \mathrm{pH} /$ Ion Meter. This method is referred to by [49], as method A4.

\subsection{Electric Conductivity}

Conductivity was determined in a aqueous extract (mixture of soil and water in the proportion $1: 5(v / v))[49,50]$.

\section{9. "Available" Phosphorus and Potassium}

Extractable phosphorus, potassium and sodium, commonly referred to as "available", were extracted with a solution of ammonium lactate and acetic acid buffered at $\mathrm{pH}$ between 3.65 and 3.75 [51]. Phosphorus assay was done by molecular absorption spectrophotometry at $650 \mathrm{~nm}$ (UNICAM UV/VIS spectrometer UV2) after color development by addition of an ammonium molybdate and ascorbic acid mixture. The determination of potassium and sodium is done by atomic absorption spectrophotometry on a Perkin Elmer Analyzer A300 apparatus. 


\subsection{Extractable Microelements (Cadmium, Chromium, Copper, Manganese, Nickel, Lead, Zinc)}

These microelements were extracted by an extractive solution composed of ammonium acetate, acetic acid and EDTA, according to the method of Lakanen and Ervio [52]. The determination of these elements was done by atomic absorption spectrophotometry in a Perkin Elmer Analyzer A300 apparatus.

\subsection{Statistical Treatment of the Results}

Analysis of variance (ANOVA) and the Duncan test (at $p<0.05$ ) for equality of means were used to detect significant differences. The statistical treatment of the obtained results was made using SPSS software version 23 from International Business Machines (IBM), Armonk, New York, United States of America.

\section{Results}

\subsection{Organic Carbon}

As it can be seen in Figure 4, the evolution of the organic carbon content of the soil in the study area, during the seven-year period under analysis, does not present a consistent variation trend. However, a similar analysis considering each soil types present on the study area, enable us to verify that while in the Cambisols and the Vertisols the variation of the organic carbon content during seven years is practically zero, in Leptosols, Luvisols and Podzois, Soil with poorer organic carbon, it is possible to observe an increasing trend, which though without statistical significance highlights a tendency that might be of interest (an attempt to establish a linear relationship between time and organic carbon content, was also performed, showing also no statistical significant relations).

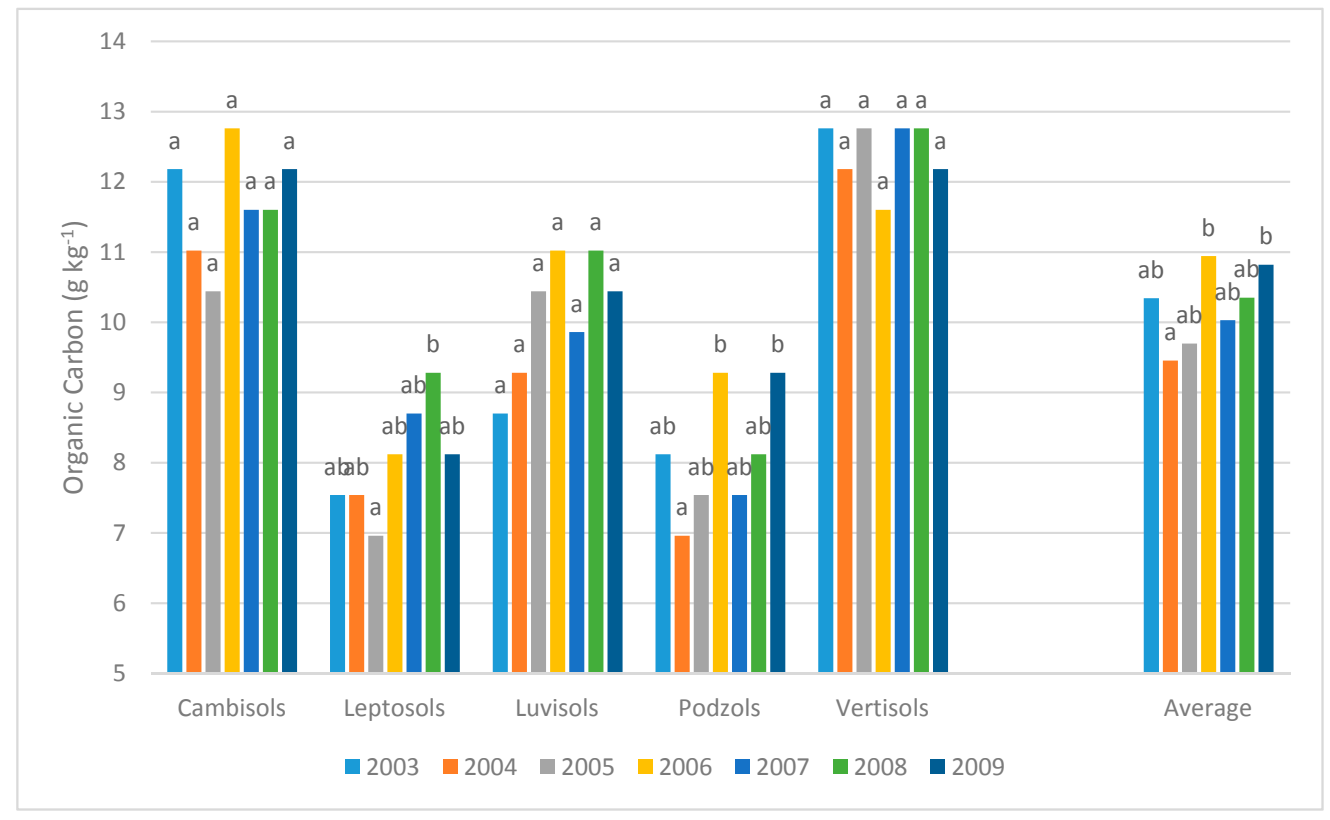

Figure 4. Annual evolution of organic carbon (2003-2009) in plots subject to European Union (EU) agro-environmental measure "Extensive Forage Systems".

\section{2. $p H$}

With the exception of soils classified as Podzols, which present $\mathrm{pH}$ values that can be classified as acids, the remaining soil types present $\mathrm{pH}$ values that might be classified as slightly acid to neutral (Figure 5). 


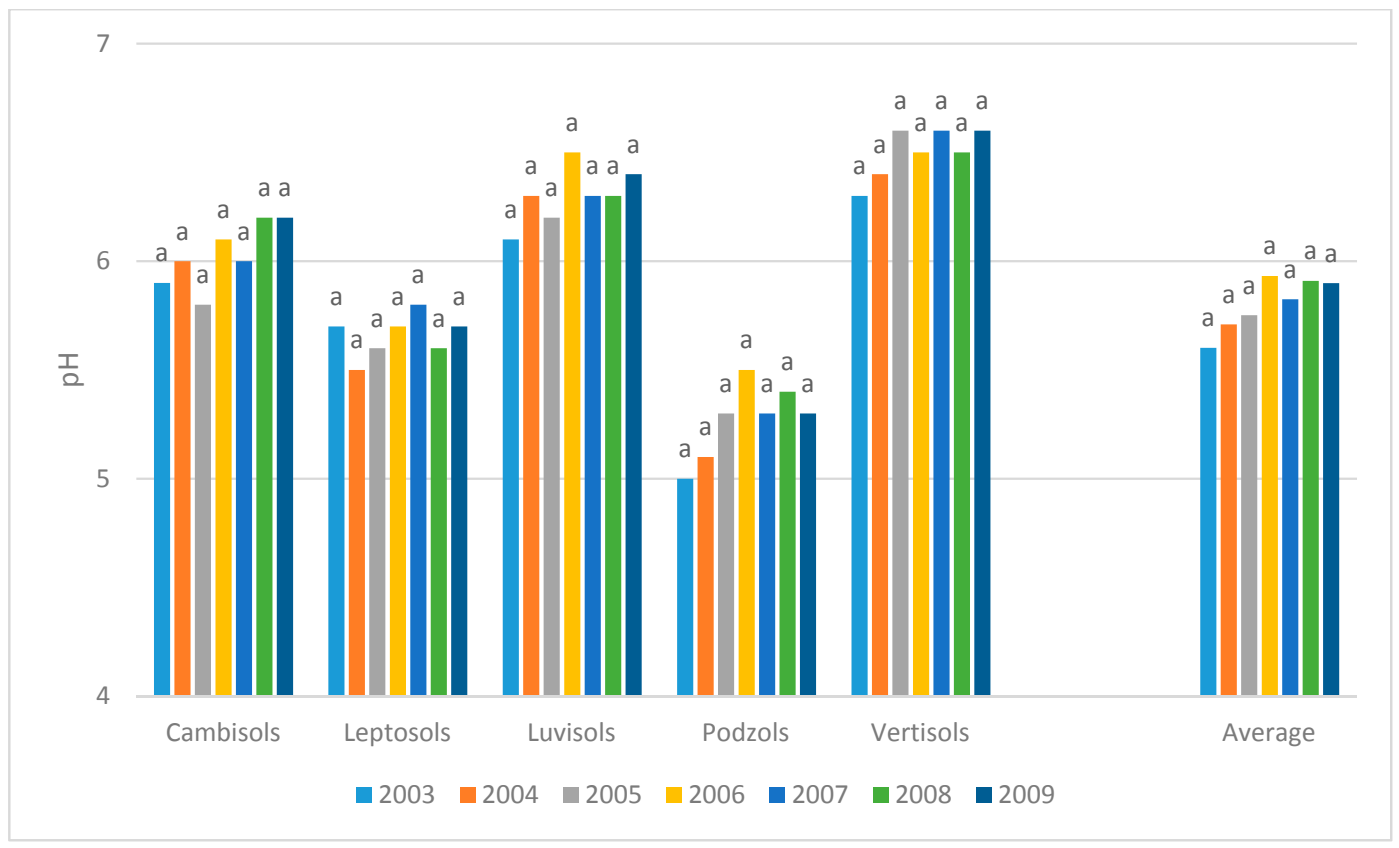

Figure 5. Annual evolution of $\mathrm{pH}$ values (2003-2009) in plots subject to EU agro-environmental measure "Extensive Forage Systems".

\subsection{Electric Conductivity}

As observed on the following figure (Figure 6) there is a statistically significant trend towards an increase on the electrical conductivity, in all the considered soil types, over the study period. This trend is particularly evident after four years under the Extensive Forage Systems Community measure.

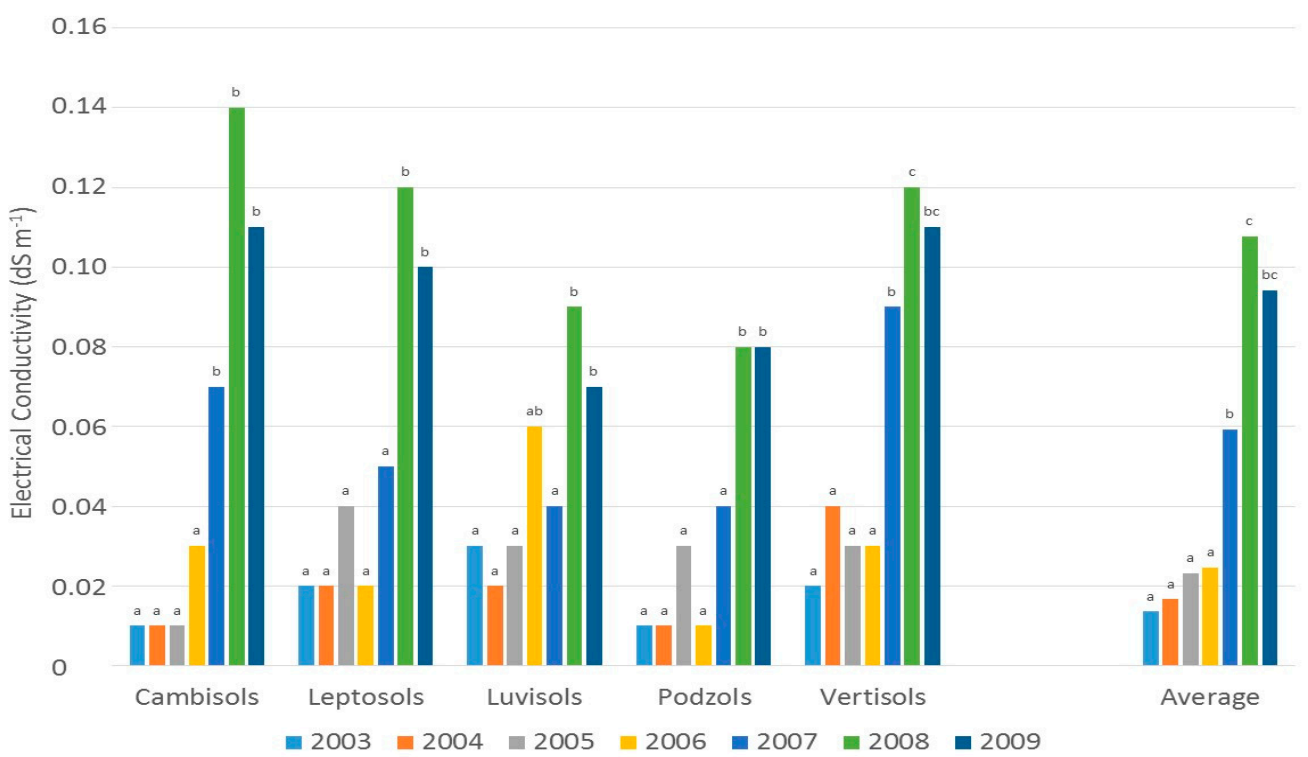

Figure 6. Annual evolution of the Electric Conductivity values (2003-2009) in plots submitted to the EU agro-environmental measure "Extensive Forage Systems". 


\section{4. "Available" Phosphorus and Potassium}

Regarding phosphorus content, the study area present values classified as "medium" (50 to $100 \mathrm{mg} \mathrm{kg}^{-1}$ ) to "high" (100 to $200 \mathrm{mg} \mathrm{kg}^{-1}$ ) [51] (Figure 7). In regard to potassium, according to the same classification, the registered contents are classified as "high" [51] (Figure 8).

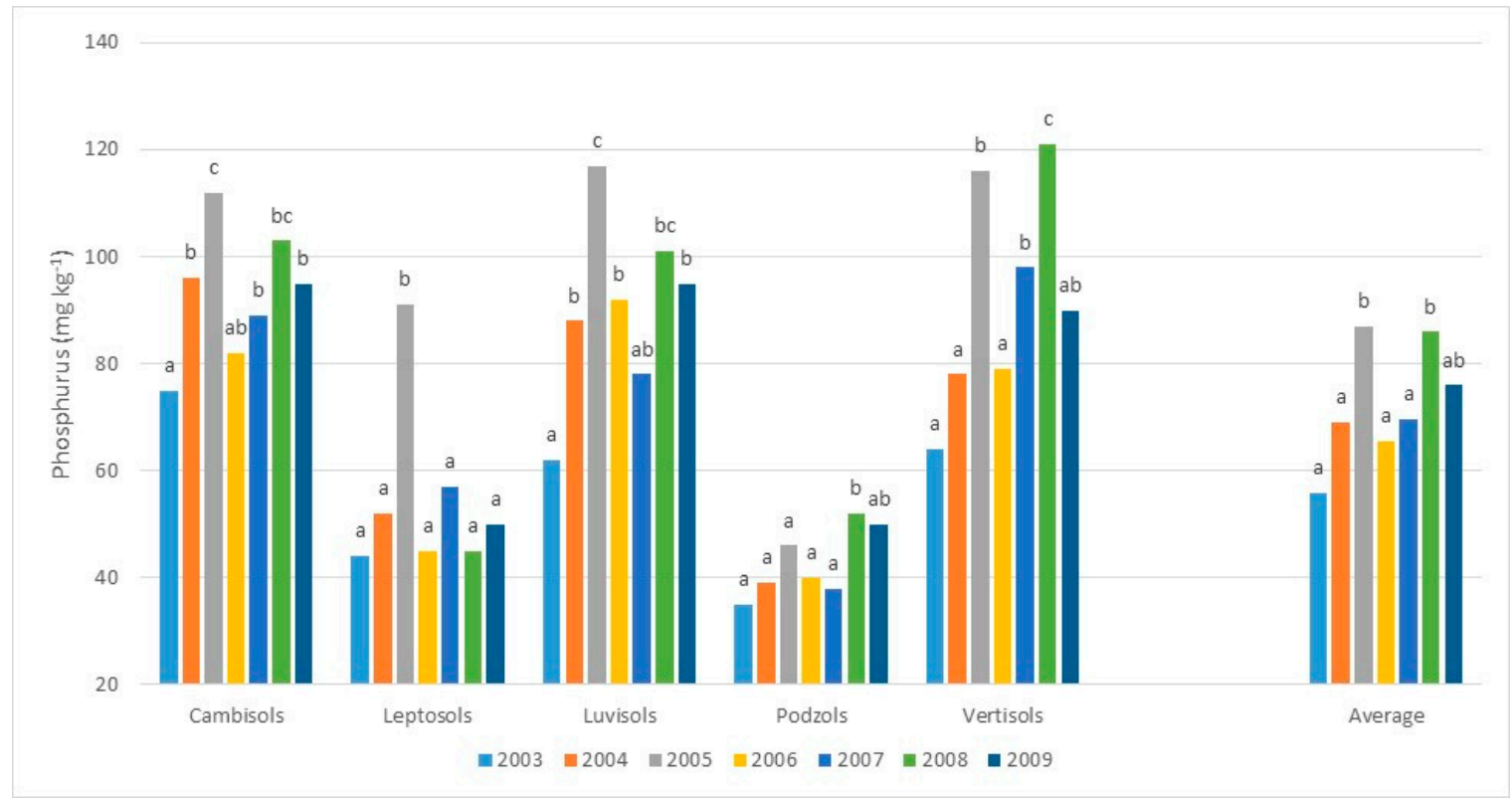

Figure 7. Annual evolution of "available" phosphorus (2003-2009) in plots subject to EU agri-environmental measure "Extensive Forage Systems".

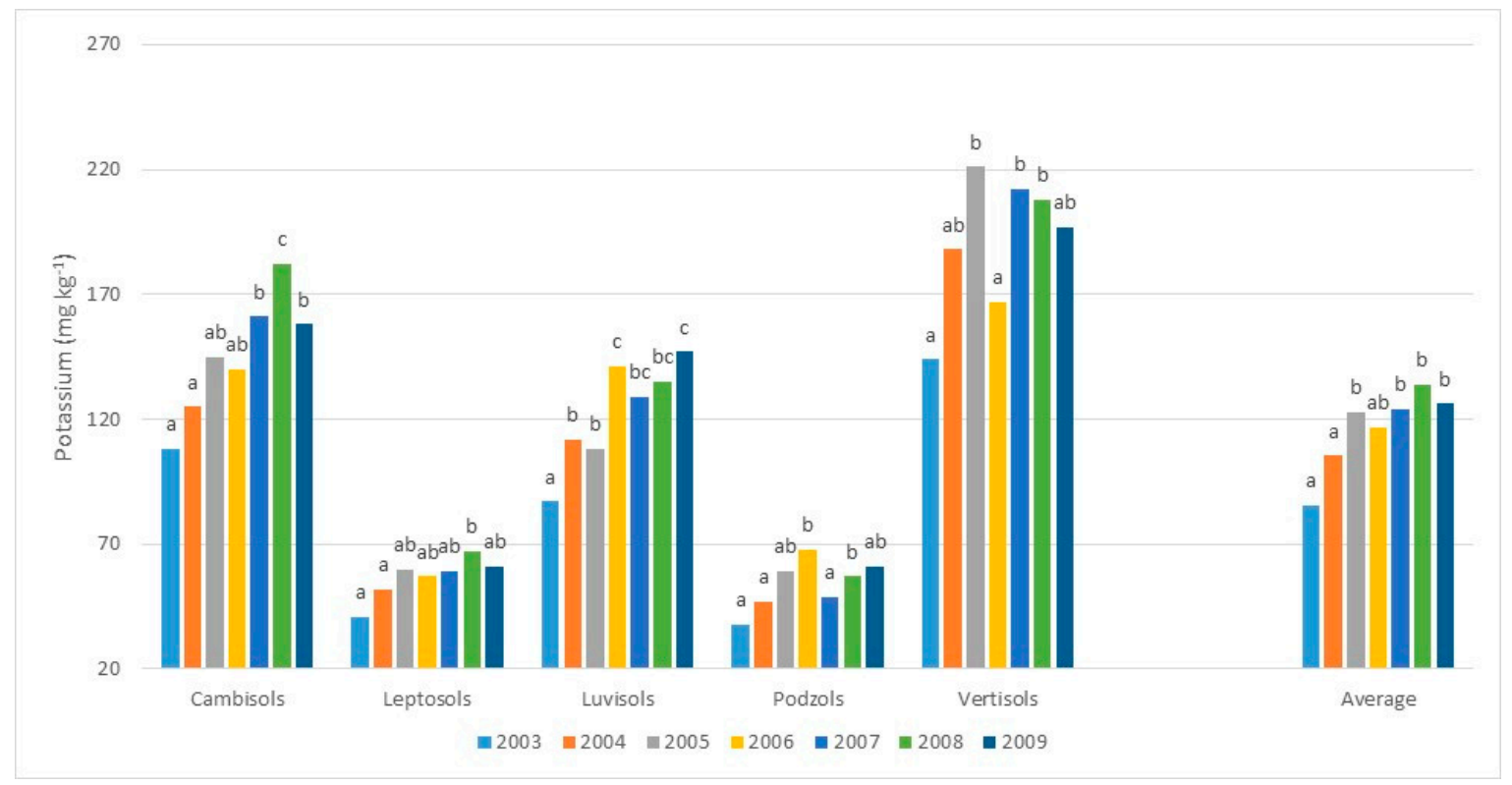

Figure 8. Annual evolution of "available" potassium (2003-2009) in plots subject to EU agri-environmental measure "Extensive Forage Systems".

\subsection{Heavy Metals (Cd, Cr, Cu, Zn, Mn, Pd, and Al)}

As it is possible to verify on Table 1 , heavy metals presented very small variations, during the period in which the study took place, showing no statistical significance and no clear evolution trend. 
Table 1. Annual evolution of the heavy metals (cadmium, chromium, copper, zinc, manganese, lead and nickel) (2003-2009) in plots subject to EU agro-environmental measure "Extensive Forage Systems".

\begin{tabular}{|c|c|c|c|c|c|c|c|}
\hline & & Cambisols & Vertisols & Leptosols & Luvisols & Podzols & AVERAGE \\
\hline \multirow{7}{*}{ Cadmium } & 2003 & $0.03 \mathrm{a}$ & $0.26 \mathrm{a}$ & $0.11 \mathrm{a}$ & $0.14 \mathrm{a}$ & $0.09 \mathrm{a}$ & $0.09 \mathrm{a}$ \\
\hline & 2004 & $0.07 \mathrm{a}$ & $0.31 \mathrm{a}$ & $0.09 \mathrm{a}$ & $0.22 \mathrm{a}$ & $0.07 \mathrm{a}$ & $0.12 \mathrm{a}$ \\
\hline & 2005 & $0.18 \mathrm{a}$ & $0.37 \mathrm{a}$ & $0.27 \mathrm{a}$ & $0.26 \mathrm{a}$ & $0.12 \mathrm{a}$ & $0.20 \mathrm{a}$ \\
\hline & 2006 & $0.08 \mathrm{a}$ & $0.33 \mathrm{a}$ & $0.22 \mathrm{a}$ & $0.17 \mathrm{a}$ & $0.08 \mathrm{a}$ & $0.12 \mathrm{a}$ \\
\hline & 2007 & $0.20 \mathrm{a}$ & $0.30 \mathrm{a}$ & $0.14 \mathrm{a}$ & $0.19 \mathrm{a}$ & $0.14 \mathrm{a}$ & $0.17 \mathrm{a}$ \\
\hline & 2008 & $0.08 \mathrm{a}$ & $0.41 \mathrm{a}$ & $0.15 \mathrm{a}$ & $0.23 \mathrm{a}$ & $0.09 \mathrm{a}$ & $0.14 \mathrm{a}$ \\
\hline & 2009 & $0.09 \mathrm{a}$ & $0.32 \mathrm{a}$ & $0.18 \mathrm{a}$ & $0.21 \mathrm{a}$ & $0.07 \mathrm{a}$ & $0.13 \mathrm{a}$ \\
\hline \multirow{7}{*}{ Chromium } & 2003 & $0.32 \mathrm{a}$ & $1.07 \mathrm{a}$ & $0.67 \mathrm{a}$ & $1.02 \mathrm{ab}$ & $0.54 \mathrm{a}$ & $0.76 \mathrm{a}$ \\
\hline & 2004 & $0.43 \mathrm{a}$ & $0.93 \mathrm{a}$ & $0.98 \mathrm{a}$ & $1.17 \mathrm{ab}$ & $0.76 \mathrm{ab}$ & $0.85 \mathrm{a}$ \\
\hline & 2005 & $1.34 \mathrm{~b}$ & $1.34 \mathrm{a}$ & $0.99 \mathrm{a}$ & $1.30 \mathrm{~b}$ & $1.12 \mathrm{~b}$ & $1.28 \mathrm{~b}$ \\
\hline & 2006 & $1.10 \mathrm{~b}$ & $1.11 \mathrm{a}$ & $1.00 \mathrm{a}$ & $1.12 \mathrm{ab}$ & $1.03 \mathrm{ab}$ & $1.09 \mathrm{ab}$ \\
\hline & 2007 & $0.36 \mathrm{a}$ & $1.24 \mathrm{a}$ & $0.40 \mathrm{a}$ & $0.48 \mathrm{a}$ & $0.56 \mathrm{a}$ & $0.58 \mathrm{a}$ \\
\hline & 2008 & $0.45 \mathrm{a}$ & $0.98 \mathrm{a}$ & $0.62 \mathrm{a}$ & $0.61 \mathrm{a}$ & $0.42 \mathrm{a}$ & $0.63 \mathrm{a}$ \\
\hline & 2009 & $0.49 \mathrm{a}$ & $1.15 \mathrm{a}$ & $0.54 \mathrm{a}$ & $0.57 \mathrm{a}$ & $0.53 \mathrm{a}$ & $0.65 \mathrm{a}$ \\
\hline \multirow{7}{*}{ Copper } & 2003 & $0.71 \mathrm{a}$ & $1.33 \mathrm{a}$ & $1.74 \mathrm{a}$ & $1.45 \mathrm{a}$ & $0.66 \mathrm{a}$ & $1.19 \mathrm{a}$ \\
\hline & 2004 & $0.84 \mathrm{a}$ & $1.56 \mathrm{a}$ & $1.63 \mathrm{a}$ & $1.56 \mathrm{a}$ & $0.69 \mathrm{a}$ & $1.31 \mathrm{a}$ \\
\hline & 2005 & $0.93 \mathrm{a}$ & $1.77 \mathrm{a}$ & $1.87 \mathrm{a}$ & $1.89 \mathrm{a}$ & $0.67 \mathrm{a}$ & $1.53 \mathrm{a}$ \\
\hline & 2006 & $0.65 \mathrm{a}$ & $1.52 \mathrm{a}$ & $1.54 \mathrm{a}$ & $1.78 \mathrm{a}$ & $0.48 \mathrm{a}$ & $1.32 \mathrm{a}$ \\
\hline & 2007 & $0.75 \mathrm{a}$ & $1.67 \mathrm{a}$ & $1.34 \mathrm{a}$ & $1.45 \mathrm{a}$ & $0.55 \mathrm{a}$ & $1.24 \mathrm{a}$ \\
\hline & 2008 & $0.73 \mathrm{a}$ & $1.88 \mathrm{a}$ & $1.72 \mathrm{a}$ & $1.67 \mathrm{a}$ & $0.68 \mathrm{a}$ & $1.39 \mathrm{a}$ \\
\hline & 2009 & $0.78 \mathrm{a}$ & $1.75 \mathrm{a}$ & $1.83 \mathrm{a}$ & $1.98 \mathrm{a}$ & $0.71 \mathrm{a}$ & $1.51 \mathrm{a}$ \\
\hline \multirow{7}{*}{ Zinc } & 2003 & $0.41 \mathrm{a}$ & $0.36 \mathrm{a}$ & $1.14 \mathrm{a}$ & $0.85 \mathrm{a}$ & $1.03 \mathrm{a}$ & $0.75 \mathrm{a}$ \\
\hline & 2004 & $0.54 \mathrm{a}$ & $0.39 \mathrm{a}$ & $1.03 \mathrm{a}$ & $0.96 \mathrm{a}$ & $1.26 \mathrm{a}$ & $0.87 \mathrm{a}$ \\
\hline & 2005 & $0.63 \mathrm{a}$ & $0.37 \mathrm{a}$ & $1.27 \mathrm{a}$ & $1.29 \mathrm{a}$ & $1.47 \mathrm{a}$ & $1.09 \mathrm{a}$ \\
\hline & 2006 & $0.35 \mathrm{a}$ & $0.18 \mathrm{a}$ & $0.94 \mathrm{a}$ & $1.18 \mathrm{a}$ & $1.22 \mathrm{a}$ & $0.88 \mathrm{a}$ \\
\hline & 2007 & $0.45 \mathrm{a}$ & $0.25 \mathrm{a}$ & $0.74 \mathrm{a}$ & $0.85 \mathrm{a}$ & $1.37 \mathrm{a}$ & $0.80 \mathrm{a}$ \\
\hline & 2008 & $0.43 \mathrm{a}$ & $0.38 \mathrm{a}$ & $1.12 \mathrm{a}$ & $1.07 \mathrm{a}$ & $1.58 \mathrm{a}$ & $0.95 \mathrm{a}$ \\
\hline & 2009 & $0.48 \mathrm{a}$ & $0.41 \mathrm{a}$ & $1.23 \mathrm{a}$ & $1.38 \mathrm{a}$ & $1.45 \mathrm{a}$ & $1.07 \mathrm{a}$ \\
\hline \multirow{7}{*}{ Manganese } & 2003 & $47.0 \mathrm{a}$ & $22.0 \mathrm{a}$ & $42.0 \mathrm{a}$ & $31.0 \mathrm{a}$ & $53.0 \mathrm{a}$ & $41.2 \mathrm{a}$ \\
\hline & 2004 & $39.0 \mathrm{a}$ & $19.0 \mathrm{a}$ & $37.0 \mathrm{a}$ & $45.0 \mathrm{ab}$ & $59.0 \mathrm{a}$ & $44.7 \mathrm{a}$ \\
\hline & 2005 & $49.0 \mathrm{a}$ & $31.0 \mathrm{ab}$ & $35.0 \mathrm{a}$ & $51.0 \mathrm{~b}$ & $65.0 \mathrm{a}$ & $51.3 \mathrm{a}$ \\
\hline & 2006 & $41.0 \mathrm{a}$ & $43.0 \mathrm{~b}$ & $45.0 \mathrm{a}$ & $36.0 \mathrm{a}$ & $41.0 \mathrm{a}$ & $39.1 \mathrm{a}$ \\
\hline & 2007 & $31.0 \mathrm{a}$ & $29.0 \mathrm{ab}$ & $29.0 \mathrm{a}$ & $33.0 \mathrm{a}$ & $57.0 \mathrm{a}$ & $36.5 \mathrm{a}$ \\
\hline & 2008 & $53.0 \mathrm{a}$ & $27.0 \mathrm{a}$ & $41.0 \mathrm{a}$ & $47.0 \mathrm{ab}$ & $49.0 \mathrm{a}$ & $48.5 \mathrm{a}$ \\
\hline & 2009 & $55.0 \mathrm{a}$ & $38.0 \mathrm{ab}$ & $39.0 \mathrm{a}$ & $33.0 \mathrm{a}$ & $47.0 \mathrm{a}$ & $43.2 \mathrm{a}$ \\
\hline \multirow{7}{*}{ Lead } & 2003 & $1.94 \mathrm{a}$ & $1.11 \mathrm{a}$ & $2.15 \mathrm{a}$ & $1.15 \mathrm{a}$ & $3.15 \mathrm{a}$ & $2.67 \mathrm{a}$ \\
\hline & 2004 & $2.11 \mathrm{a}$ & $1.97 \mathrm{~b}$ & $2.89 \mathrm{a}$ & $1.79 \mathrm{~b}$ & $3.79 \mathrm{a}$ & $3.90 \mathrm{~b}$ \\
\hline & 2005 & $2.78 \mathrm{~b}$ & $1.77 \mathrm{ab}$ & $2.93 \mathrm{a}$ & $1.67 \mathrm{~b}$ & $4.11 \mathrm{a}$ & $4.11 \mathrm{~b}$ \\
\hline & 2006 & $2.71 \mathrm{~b}$ & $2.15 \mathrm{~b}$ & $3.17 \mathrm{a}$ & $2.25 \mathrm{c}$ & $3.89 \mathrm{a}$ & $4.48 \mathrm{~b}$ \\
\hline & 2007 & $2.22 \mathrm{a}$ & $1.63 \mathrm{ab}$ & $2.77 \mathrm{a}$ & $1.93 \mathrm{~b}$ & $2.97 \mathrm{a}$ & $3.93 \mathrm{ab}$ \\
\hline & 2008 & $1.87 \mathrm{a}$ & $1.65 \mathrm{ab}$ & $2.07 \mathrm{a}$ & $0.87 \mathrm{a}$ & $2.57 \mathrm{a}$ & $3.27 \mathrm{a}$ \\
\hline & 2009 & $2.83 \mathrm{~b}$ & $2.17 \mathrm{~b}$ & $2.59 \mathrm{a}$ & $1.35 \mathrm{a}$ & $3.99 \mathrm{a}$ & $4.42 \mathrm{~b}$ \\
\hline \multirow{7}{*}{ Niquel } & 2003 & $1.45 \mathrm{a}$ & $3.15 \mathrm{a}$ & $1.15 \mathrm{a}$ & $1.55 \mathrm{a}$ & $2.15 \mathrm{a}$ & $1.50 \mathrm{a}$ \\
\hline & 2004 & $2.35 \mathrm{~b}$ & $3.95 \mathrm{a}$ & $1.95 \mathrm{~b}$ & $1.79 \mathrm{a}$ & $2.30 \mathrm{a}$ & $2.07 \mathrm{ab}$ \\
\hline & 2005 & $2.55 \mathrm{~b}$ & $3.27 \mathrm{a}$ & $2.77 \mathrm{c}$ & $2.15 \mathrm{a}$ & $2.87 \mathrm{a}$ & $2.45 \mathrm{~b}$ \\
\hline & 2006 & $1.74 \mathrm{a}$ & $2.96 \mathrm{a}$ & $1.95 \mathrm{~b}$ & $1.45 \mathrm{a}$ & $1.95 \mathrm{a}$ & $1.67 \mathrm{a}$ \\
\hline & 2007 & $1.55 \mathrm{a}$ & $2.80 \mathrm{a}$ & $1.37 \mathrm{ab}$ & $1.85 \mathrm{a}$ & $2.25 \mathrm{a}$ & $1.77 \mathrm{a}$ \\
\hline & 2008 & $1.15 \mathrm{a}$ & $2.57 \mathrm{a}$ & $1.18 \mathrm{a}$ & $1.35 \mathrm{a}$ & $1.75 \mathrm{a}$ & $1.33 \mathrm{a}$ \\
\hline & 2009 & $1.40 \mathrm{a}$ & $2.74 \mathrm{a}$ & $1.05 \mathrm{a}$ & $1.40 \mathrm{a}$ & $2.45 \mathrm{a}$ & $1.56 \mathrm{a}$ \\
\hline
\end{tabular}




\section{Discussion}

\subsection{Organic Carbon}

The explanation for this result, especially the ones registered for Cambisols and Vertisols, is that the soil organic carbon content is a slow evolution parameter [53] and that the study period, short from a pedological point of view, was not sufficient for its significant evolution. Another possible explanation is that many of these soils, were already under permanent pasture in their natural environment, prior to the implementation of the EU environmental preservation policy [18] because they were not suitable for more demanding crops and, consequently, higher production [54]. As a matter of fact, according to [29], the soils of the Northeast Alentejo are characterized by very low organic carbon contents, rarely reaching $1.5 \%$ still, in this study, initial organic carbon contents were already slightly above the $2 \%$, values that indicate that even without the implementation of the addressed EU policies these soils were already submitted to conservation practices for several years, sometimes decades. Another fact that undoubtedly helps to justify these results is that extensive forage systems are of low productivity with low biomass production only allowing for reduced livestock [55] and, thus, leading to a particularly slow process regarding the increase of the soil organic carbon content. If we compare this results with the ones obtained by other authors [53-56] we verify that when an extensive forage system replaces an annual crop, which did not happen on the majority of the analyzed plots in this study, increases in the organic carbon content in the soil are more prominent and generally significant. However, in the performed study, the explorations starting point were parcels that were already under the extensive forage system of exploitation and the farmers only adhered to these measures given the economic support that would come to them. In this case, and as demonstrated in the study of [57], the organic carbon content changes very slowly and even slower as the system tends to equilibrium.

\section{2. $p H$}

The obtained results show that in none of the considered soil types there were significant evolutions of $\mathrm{pH}$ values over the period under analysis. This fact might be related to the increase of soil buffering power due to the tendency previously mentioned related to the minor increase in soil organic matter content, which is opposed to more evident $\mathrm{pH}$ changes [29].

As matter of fact, in the case of rainfed agricultural systems and soils with reasonable organic matter content for the region, soil buffering capacity lead to no substantial change of this parameter value $[26,50]$ which, coupled with the fact that these soils do not receive relevant amounts of fertilizers, turn clear the inexistence of factors leading to substantial changes in $\mathrm{pH}$ values [58]. The results obtained in this study corroborate with the ones obtained on previous research $[57,58]$ which indicate a maintenance of $\mathrm{pH}$ values in the extensive forage systems and, in some cases, given the strengthening of the soil exchange complex, in particular due to the increase in organic matter (tendency that was not confirmed on the present study), even indicate a slight inclination for a rise in $\mathrm{pH}$ values due to an increase on the concentration of the soil exchange bases.

\subsection{Electric Conductivity}

Though similar results were found in previous studies [57,58], according to $[29,30,53,54,56]$, with the increase of the organic matter content expected in these agro-systems-impossible to confirm in this study-the soil acquires a stronger and defined structure which allows for a better infiltration rate and, with this phenomenon, to a substantial improvement regarding the superficial washing of the existing salts with the consequent decrease of the soil EC values. One possible explanation for this result, as far as we are concerned, is that the legislation provides for no soil mobilization and thus there is a natural tendency for a lower rate of water infiltration, with the consequent increase of the salt content at the soil surface. The fact that the organic matter content remained practically constant throughout the study period did not allow the expected improvement in the soil structure, which would potentially lead to an increase in the internal drainage of these soils $[53,54,56]$. 
Finally, it should be noted that, despite the significant increase in the value of this parameter, the EC values found in these soils are very distant from the ones indicated on the literature as potentially dangerous for meadow species' germination and growth [59].

\section{4. "Available" Phosphorus and Potassium}

The levels of assimilable phosphorus over the period under review, albeit in a non-linear fashion, show a statistically significant increasing trend for Cambisols, Luvisols and Vertisols. This result is related to the fact that a significant proportion of these soils were abandoned or with unfertilized natural pasture, before the implementation of the community incentive, situation that is significantly changed after the application of the EFS measure, when pastures are ameliorated and/or fertilized, in most cases exclusively by phosphorus, leading to the aforementioned result. In a more detailed analysis, it is possible to observe that, with the exception of Leptosols and Podzols (where the registered variations have no statistical significance), the other types of soil present a significant increase in the level of "available" phosphorus during the first three years of the study. This result, to the best of our knowledge, had not been presented by other authors assessing similar issues $[29,30,60,61]$, as previously mentioned, due to the fact that pastures sown in this system are subject to phosphate fertilization during installation, operation that will only be repeated 3 or 4 years later. This fact is also evidenced by the results obtained in the following triennium, where the three-year growth cycle of assimilable phosphorus levels, particularly evident in soils classified as Cambisols and Vertisols, is clearly verified. This variation lead us to conclude that these analyzes must, in fact, be carried out in relatively long time series, since the analysis made only in the first three years of the implementation of this community measure would lead us to draw necessarily erroneous conclusions.

Regarding the results obtained for the "assimilable" potassium available in the soils, there is a statistically significant trend in the case of the Cambisols and Luvisols to increase the content of this nutrient over the period under analysis. The explanation for this result can be found in the slight increase verified on the organic matter content of the soil, since this nutrient is not, in the overwhelming majority of cases, applied on the fertilizer form $[29,30]$. The results obtained for both phosphorus and potassium are similar to those reported by other authors $[60,61]$. However, the observed changes are smaller than the ones expected and reported previous studies [37,61]. It seems that in this case the implementation of EAM had a positive result in the majority of soil types studied.

This reality might be due to the fact these soils present already medium to high levels of phosphorus and potassium, making that any increments on these elements will necessarily be less evident and more slowly registered. Another aspect to be emphasized, in the scope of this study, was the registered medium to high levels of phosphorus, that are not in line with the generalized data regarding the soils of Northeast Alentejo, which are characterized by very low ( 0 to $\left.25 \mathrm{mg} \mathrm{kg}^{-1}\right)$ to low (25 to $50 \mathrm{mg} \mathrm{kg}^{-1}$ ) phosphorus levels [29,37]. The explanation for this result may be related, firstly, to some phosphorus fertilization, carried out when implementing the bio-diverse pasture inherent to the Extensive Forage Systems, as previously mentioned; and secondly, because some of these soils were kept natural, or mainly dedicated to extensive pasture for several years, which lead to fertility levels that would already be logically better than those normally found in the region's agricultural soils.

\subsection{Heavy Metals (Cd, Cr, Cu, Zn, Mn, Pd, and Al)}

Although, with no statistical significance, the registered variations on Chromium, Cadmium, Copper, Nickel and Lead demonstrate an increasing tendency during the first three years of the assay, after which they decrease and stabilize. These changes in heavy metals content are in line with the consulted literature [23,40,62-65]. Furthermore, the obtained results (low levels of heavy metals recorded and non-significant evolution of this parameter over time) were along with the expectations, considering both the characteristics of the study area (a natural landscape free of pollution incidents, with very low levels of industrialization), and the implemented cultural system in which the amount of fertilizers and phytosanitaries applied is very low $[29,54]$. 


\section{Conclusions}

From the results obtained in the present study we conclude that, under typical Mediterranean conditions, the application of the EU AEM known as "Extensive Forage Systems" did not lead, at least during the first 7 years of its application, to significant changes to the soils organic carbon and $\mathrm{pH}$, independently from the soils group under analysis. Regarding Soil EC, there was a significant increase on the registered values during the study period, particularly evident on Cambisols and Vertisols and after the first three years of the application of the EMP under analysis. The "assimilable" phosphorus and potassium contents have a significant tendency in the case of Cambisols and Luvisols to grow during this period, which, especially in the case of phosphorus, is directly related to fertilization. In the case of the "assimilable" phosphorous, the growth observed seems to be in line with the normal cycle of fertilizer application, with increases during the first year followed by a decrease in the next two years and again a growth on the following year. In regard to the content of $\mathrm{Cd}, \mathrm{Cr}, \mathrm{Cu}, \mathrm{Zn}, \mathrm{Mn}, \mathrm{Pb}$ and $\mathrm{Ni}$, independently of the group of soils under analysis, the levels of these elements in the soil don't change significantly between the beginning and the end of the experimental period.

As a final conclusion of this study, we can say that the application of AEM, under the soil, climatic and agricultural conditions of the study region, allowed a significant increase in assimilable phosphorus and potassium levels, which, although not one of the main objectives of these measures, has to be highlighted given its importance in soil fertility. However, the application of these measures did not lead to significant increases in the organic carbon content of the soil, and this is not according to what is presented as one of the main objectives of this agro-environmental measure.

Acknowledgments: The authors would like to acknowledge the support given by national funds from Fundação para a Ciência e Tecnologia through the research unit UID/AGR/04129/2013 (LEAF) and also to Luis Loures as a Post-Doc fellow at GORSAS (Research Group on Soils, Water and Sediments Management, Conservation and Recovery)-Universidad de Extremadura.

Author Contributions: José Nunes, António Bonito and Angel Albarrán designed the research; José Gama and David Peña performed the analysis; José Nunes and Luís Loures analyzed the data; António López-Piñeiro and José gama contributed with analysis tools and; José Nunes, Luís Loures and António López-Piñeiro wrote the paper. All authors read and approved the final manuscript.

Conflicts of Interest: The authors declare no conflict of interest.

\section{References}

1. Zdruli, P. Land resources of the Mediterranean: Status, pressures, trends and impacts on future regional development. Land Degrad. Dev. 2014, 25, 373-384. [CrossRef]

2. Plieninger, T.; Hartel, T.; Martín-López, B.; Beaufoy, G.; Bergmeier, E.; Kirby, K.; Montero, M.J.; Moreno, G.; Oteros-Rozas, E.; Uytvanck, J. Wood-pastures of Europe: Geographic coverage, social-ecological values, conservation management, and policy implications. Biol. Conserv. 2015, 190, 70-79. [CrossRef]

3. Villanueva, A.J.; Gómez-Limón, J.A.; Arriaza, M.; Rodríguez-Entrena, M. The design of agri-environmental schemes: Farmers' preferences in southern Spain. Land Use Policy 2015, 46, 142-154. [CrossRef]

4. European Soil Bureau Network/European Commission. Soil Atlas of Europe; Office for Official Publications of the European Communities: Brussels, Belgium, 2005.

5. Batáry, P.; Dicks, L.V.; Kleijn, D.; Sutherland, W.J. The role of agri-environment schemes in conservation and environmental management. Conserv. Biol. 2015, 29, 1006-1016. [CrossRef] [PubMed]

6. Antle, J.; Lekakis, J.; Zanias, G. Agriculture, Trade and the Environment: The Impact of Liberalization on Sustainable Development; Virginia Tech Ed: Blacksburg, VA, USA, 2016.

7. Comissão Europeia. Plano de Acção em Matéria de Biodiversidade Para a Agricultura; Comissão Europeia: Brussels, Belgium, 2001.

8. Hodge, I.; Hauck, J.; Bonn, A. The alignment of agricultural and nature conservation policies in the European Union. Conserv. Biol. 2015, 29, 996-1005. [CrossRef] [PubMed]

9. Hine, R.C.; Ingersent, K.A.; Rayner, A.J. The Reform of the Common Agricultural Policy; Springer: Berlin, Germany, 2016, ISBN 1349261017, 9781349261017. 
10. Comissão Europeia. Adapting to Climate Change in Europe-Options for EU Action; Comissão Europeia: Brussels, Belgium, 2007.

11. Rounsevell, M.; Evans, S.P.; Bullock, P. Climate Change and Agricultural Soils: Impacts and Adaptation. Clim. Chang. 1999, 43, 683-709. [CrossRef]

12. Schröter, D.W.; Cramer, R.; Leemans, I.C.; Prentice, M.B.; Araújo, A.W.; Arnell, A.; Bondeau, H.; Bugmann, T.; Carter, C.A.; Gracia, A.C.; et al. Ecosystem Service Supply and Vulnerability to Global Change in Europe. Science 2005, 310, 1333-1337. [CrossRef] [PubMed]

13. European Union. Regulation (EU) No. 1305/2013 of the European Parliament and of the Council of 17 December 2013 on Support for Rural Development by the European Agricultural Fund for Rural Development (EAFRD) and Repealing Council Regulation (EC) No. 1698/2005. Off. J. Eur. Union 2013, 347, 487-584.

14. Grinsven, H.; Erisman, J.W.; Vries, W.; Westhoek, H. Potential of extensification of European agriculture for a more sustainable food system, focusing on nitrogen. Environ. Res. Lett. 2015, 10, 2. [CrossRef]

15. Merckx, T.; Pereira, H. Reshaping agri-environmental subsidies: From marginal farming to large-scale rewilding. Basic Appl. Ecol. 2015, 16, 95-103. [CrossRef]

16. Miglietta, P.P.; De Leo, F.; Massari, S. Water footprint assessment of some Italian wines: A territorial perspective. Int. J. Environ. Policy Decis. Mak. 2015, 4, 320-331. [CrossRef]

17. European Union. Regulation (EU) No. 1307/2013 of the European Parliament and of the Council of 17 December 2013 Establishing Rules for Direct Payments to Farmers Under Support Schemes within the Framework of the Common Agricultural Policy and Repealing Council Regulation (EC) No. 637/2008 and Council Regulation (EC) No. 73/2009. Off. J. Eur. Union 2013, 347, 608-670.

18. Comissão Europeia. Orientaciones Para una Agricultura Sostenible; Comissão Europeia: Brussels, Belgium, 1999.

19. Instituto Nacional de Estatistica. Censos 2011-Resultados Preliminares; Instituto Nacional de Estatistica: Lisbon, Portugal, 2011.

20. Diário da Republica Portuguesa. Portaria n. ${ }^{\circ}$ 1212/2003, DR 240 SÉRIE I-B; ICNF: Lisbon, Portugal, 2003.

21. Muñoz-Rojas, M.; Jordán, A.; Zavala, L.M.; De la Rosa, D.; Abd-Elmabod, S.K.; Anaya-Romero, M. Impact of Land Use and Land Cover Changes on Organic Carbon Stocks in Mediterranean Soils (1956-2007). Land Degrad. Dev. 2015, 26, 168-179. [CrossRef]

22. Rato-Nunes, J.; Cabral, F.; López-Piñeiro, A. Short-term effects on soil properties and wheat production from secondary paper sludge application on two Mediterranean agricultural soils. Bioresour. Technol. 2008, 99, 4935-4942. [CrossRef] [PubMed]

23. Bou Kheir, R.; Shomar, B.; Greve, M.B.; Greve, M.H. On the quantitative relationships between environmental parameters and heavy metals pollution in Mediterranean soils using GIS regression-trees: The case study of Lebanon. J. Geochem. Explor. 2014, 147, 250-259. [CrossRef]

24. Panagos, P.; Borrelli, P.; Poesen, J.; Ballabio, C.; Lugato, E.; Meusburger, K.; Montanarella, L.; Alewell, C. The new assessment of soil loss by water erosion in Europe. Environ. Sci. Policy 2015, 54, 438-447. [CrossRef]

25. Parras-Alcántara, L.; Lozano-García, B.; Brevik, E.C.; Cerdá, A. Soil organic carbon stocks assessment in Mediterranean natural areas: A comparison of entire soil profiles and soil control sections. J. Environ. Manag. 2015, 155, 219-228. [CrossRef] [PubMed]

26. Laudicina, V.A.; Novara, A.; Barbera, V.; Egli, M.; Badalucco, L. Long-Term Tillage and Cropping System Effects on Chemical and Biochemical Characteristics of Soil Organic Matter in a Mediterranean Semiarid Environment. Land Degrad. Dev. 2015, 26, 45-53. [CrossRef]

27. Rato Nunes, J.; Ramos-Miras, J.; Lopez-Piñeiro, A.; Loures, L.; Gil, C.; Coelho, J.; Loures, A. Concentrations of Available Heavy Metals in Mediterranean Agricultural Soils and their Relation with Some Soil Selected Properties: A Case Study in Typical Mediterranean Soils. Sustainability 2014, 6, 9124-9138. [CrossRef]

28. Sierra, C.A.; Trumbore, S.E.; Davidson, E.A.; Vicca, S.; Janssens, I. Sensitivity of decomposition rates of soil organic matter with respect to simultaneous changes in temperature and moisture. J. Adv. Model. Earth Syst. 2015, 7, 335-356. [CrossRef]

29. Santos, J.Q. Fertilização, Fundamentos Agroambientais da Utilização dos Adubos e Corretivos; Publindústria-Produção De Comunicação Lda: Porto, Portugal, 2015, ISBN 9789897230851.

30. Varennes, A. Produtividade dos Solos e Ambiente; Livraria Escolar Editora: Maputo, Mozambique, 2003, ISBN 972-592-156-9. 
31. Lehmann, J.; Kleber, M. The contentious nature of soil organic matter. Nature 2015, 528, 60-68. [CrossRef] [PubMed]

32. Martín, J.; Álvaro-Fuentes, J.; Gonzalo, J.; Gil, C.; Ramos-Miras, J.; Grau Corbí, M.; Boluda, M. Assessment of the soil organic carbon stock in Spain. Geoderma 2016, 264, 117-125. [CrossRef]

33. Mohawesh, Y.; Taimeh, A.; Ziadat, F. Effects of land use changes and soil conservation intervention on soil properties as indicators for land degradation under a Mediterranean climate. Solid Earth 2015, 6, 857-868. [CrossRef]

34. Gruba, P.; Mulder, J. Tree species affect cation exchange capacity (CEC) and cation binding properties of organic matter in acid forest soils. Sci. Total Environ. 2015, 511, 655-662. [CrossRef] [PubMed]

35. Panghaal, D.; Sangwan, P.; Mittal, S. Effect of Tillage and Phosphorus Fertilization of Wheat on Inorganic Soil Phosphorus Fractions under Wheat-Sorghum Cropping System. Int. J. Curr. Microbiol. Appl. Sci. 2017, 6, 283-291. [CrossRef]

36. Porta, J.; Reguerín, L.; Laburu, M. Edafología para la Agricultura y el Medio Ambiente; Ediciones Mundi-Prensa: Madrid, Spain, 2003, ISBN 9788471147844.

37. Costa, C.; Papatheodorou, E.M.; Monokrousos, N.; Stamou, G.P. Spatial Variability of Soil Organic C, Inorganic N and Extractable P in a Mediterranean Grazed Area. Land Degrad. Dev. 2015, 26, 103-109. [CrossRef]

38. Tan, W.F.; Zhang, R.; Cao, H.; Huang, C.Q.; Yang, Q.K.; Wang, M.K.; Koopal, L.K. Soil inorganic carbon stock under different soil types and land uses on the Loess Plateau region of China. Catena 2014, 121, 22-30. [CrossRef]

39. Wang, L.; Liang, T. Effects of exogenous rare earth elements on phosphorus adsorption and desorption in different types of soils. Chemosphere 2014, 103, 148-155. [CrossRef] [PubMed]

40. Kelepertzis, E. Accumulation of heavy metals in agricultural soils of Mediterranean: Insights from Argolida basin, Peloponnese, Greece. Geoderma 2015, 221-222, 82-90. [CrossRef]

41. Nunes, J. Los Suelos del Perímetro Regable del Caia (Portugal): Tipos, Fertilidade, e Impacto del Riego en sus Propriedades Químicas. Ph.D. Thesis, Universidad de Extremadura, Faculdad de Ciencias, Badajoz, Spain, 2003.

42. Nunes, J.; López-Piñeiro, A.; Albarrán, A.; Muñoz, A.; Coelho, J. Changes in selected soil properties caused by 30 years of continuous irrigation under Mediterranean conditions. Geoderma 2007, 139, 321-328. [CrossRef]

43. Food and Agriculture Organization of the United Nations. World Referende Base for Soil Rsources-International Soil Classification System for Naming Soils and Creating Legends for Soil Maps; FAO: Rome, Italy, 2015, ISBN 978-92-5-108369-7.

44. Direcção Geral de Minas e Serviços Geológicos. Carta Geológica de Portugal à Escala 1:50.000; Serviços Geológicos Instituto Geográfico e Cadastral: Lisboa, Portugal, 1969.

45. Instituto de Meteorologia. Atlas Climatológico de Portugal Continental-1971-2000: Temperatura do ar e Precipitação; Instituto de Meteorologia: Lisbon, Portugal, 2009.

46. Essenwanger, O.M. General Climatology 1C: Classification of Climates; Elsevier Science: Amsterdam, The Netherlands, 2001.

47. Nelson, D.W.; Sommers, L.E. Total C, organic C and organic metter. In Methods of Soil Analysis; Sparks, D.L., Page, A.L., Helmke, P.A., Loeppert, R.H., Soltanpour, P.N., Tabatabai, M.A., Johnston, C.T., Sumner, M.E., Eds.; Soil Science Society of America Book Series No 5, Part 3-Chemical Methods; Soil Science Society of America-America Society of Agronomy Publ.: Madison, WI, USA, 1996; pp. 961-1010.

48. United State Departement of Agriculture (USDA). Soil Survey Laboratory Methods Manual; Soil Survey Investigation Report NO 42, Version 3.0; USDA: Quilcene, WA, USA, 1996; p. 692.

49. Buurman, P.; Lagen, B.; Velthorst, E. Manual for Soil and Water Analysis; Backhuys Publishers Leiden: Wageningen, The Netherlands, 1996.

50. Rhoades, J.D. Soluble salts. In Methods of Soil Analysis, 2nd ed.; Page, A.L., Miller, R.H., Keeney, D.R., Eds.; Part 2: Chemical and Microbiological Properties; American Society of Agronomy: Madison, WI, USA, 1982; Volume 9, pp. 167-179.

51. Egnér, H.; Riehm, H.; Domingo, W.R. Untersuchhungen uber die chemische boden: Analyse als grundlage fur die beurteilung der nahrstoffzustandes der boden. II. Chemique extractions, methoden zur phosphor, und kalium-bestimmung. Kungl. Lantbrukshoegsk. Ann. 1960, 26, 199-215. 
52. Cottenie, A.; Verlo, M.; Kjekens, L.; Camerlynch, R. Chemical Analysis of Plant and Soil; Laboratory of Analytical Agrochemistry, State University: Gent, Belgium, 1982; Volume 42, pp. 80-284.

53. Snapp, S.; Grandy, S. Advanced Soil Organic Matter Management (E-3137); Michigna State University Extension Bulletin; Michigna State University: East Lansing, MI, USA, 2012.

54. Reddy, P.P. Soil Organic matter. In Sustainable Intensification of Crop Production; Springer: Berlin, Germany, 2016; pp. 157-163, ISBN 978-981-10-2701-7.

55. Toshiko, M.; Kento, O.; Kazuya, N.; Muhajir, U.; Ainin, N.; Nobuhiro, K.; Koichi, F. The Effects of Nitrogen Fertilizer on Soil Microbial Communities under Conventional and Conservation Agricultural Managements in a Tropical Clay-Rich Ultisol. Soil Sci. 2016, 181, 68-74. [CrossRef]

56. Jayalath, N.; Mosley, L.M.; Fitzpatrick, R.W.; Marschner, P. Addition of organic matter influences pH changes in reduced and oxidised acid sulfate soils. Geoderma 2016, 262, 125-132. [CrossRef]

57. Hueso-González, P.; Martínez-Murillo, J.F.; Ruiz-Sinoga, J.D. The impact of organic amendments on forest soil properties under mediterranean climatic conditions. Land Degrad. Dev. 2014, 25, 604-612. [CrossRef]

58. Behera, S.K.; Shukla, A.K. Spatial Distribution of Surface Soil Acidity, Electrical Conductivity, Soil Organic Carbon Content and Exchangeable Potassium, Calcium and Magnesium in Some Cropped Acid Soils of India. Land Degrad. Dev. 2015, 26, 71-79. [CrossRef]

59. Laboratório Rebelo da Silva. Manual Prático de Fertilização das Culturas; INIAV: Lisbon, Portugal, 2000.

60. Serrano, J.M.; Shahidian, S.; Marques da Silva, J.R. Soil phosphorus retention in a Mediterranean pasture subjected to differential management. Eur. J. Soil Sci. 2014, 65, 562-572. [CrossRef]

61. Serrano, J.M.; Marques da silva, J.R.; Shahidian, S. Spatial and temporal patterns of potassium on grazed permanent pastures-Management challenges. Agric. Ecosyst. Environ. 2014, 188, 29-39. [CrossRef]

62. Esmaeili, A.; Moore, F.; Keshavarzi, B.; Jaafarzadeh, N.; Kermani, M. A geochemical survey of heavy metals in agricultural and background soils of the Isfahan industrial zone, Iran. Catena 2014, 121, 88-98. [CrossRef]

63. Roca-Perez, L.; Gil, C.; Cervera, M.L.; Gonzálvez, A.; Ramos-Miras, J.; Pons, V.; Bech, J.; Boluda, R. Selenium and heavy metals content in some Mediterranean soils. J. Geochem. Explor. 2010, 107, 110-116. [CrossRef]

64. Acosta, J.A.; Faz, A.; Martinez, M. Identification of heavy metal sources by multivariable analysis in a typical Mediterranean city (SE Spain). Environ. Monit. Assess. 2010, 169, 519-530. [CrossRef] [PubMed]

65. Marzaioli, R.; D'Ascoli, R.; De Pascale, R.A.; Rutigliano, F.A. Soil quality in a Mediterranean area of Southern Italy as related to different land use types. Appl. Soil Ecol. 2010, 44, 205-212. [CrossRef] 